\title{
The Evolution of Bankruptcy Stigma
}

\author{
Rafael Efrat ${ }^{*}$
}

Historically, individuals who fle for bankruptcy protection have been viewed harshly by society. The negative perception of bankrupts was manifested in the punitive measures employed agatinst bankruptcy petitioners, in the degrading public rituals directed at them, and in the contemptuous discourse used by officials to refer to the bankrupts. This traditional negative image of bankrupts was shared in colonial America, and vigorously continued throughout the Victorian era and into the 20th century. By the 1960s, a number of critics began to voice their concerns about the dramatic rise in consumer bankruptcy filings in the United States. The critics have mostly attributed the increase in filings 10 an alleged decline both in morals and in the shame associated with bankruptcy. Charges of the fading stigma of bankruptcy have recently intensified. A number of recent studies have attempted to corroborate assertions of the declining stigma of bankruptcy through the use of indirect variables as proxies. These attempts to measure bankruptcy stigma have been roundly criticized. The disapproval centers mainly on the studies' failure 10 directly measure changes in public perception of bankruptcy.

This study attempts to measure the evolution of stigma in bankruptcy by addressing the methodological concerns attributed to previous

* Associate Professor, College of Business \& Economics, California State University, Northridge. J.S.D., 2002, Stanford Law School; J.S.M., 1998, Stanford Law School; J.D., 1992, University of Southem California Law Center. I am grateful to Joseph W. Berriman, Keith Hamasaki, and Laura C. Gardner for their dedicated assistance in this research project. l am particularly thankful to Professor Richard Gunther for assistance with the statistical analysis of the data. l owe special thanks for valuable comments 1 received on earlier drafts from Emeritus Professor William Whitford from the University of Wisconsin Law School, Professor Todd J. Zywicki from George Mason Univesity School of Law, as well as the participants at the Cegla Center Conference on Personal Bankruptcy in the 21 st Century, held at Tel Aviv University School of Law on June 5-8, 2005. 
empirical studies on this subject. Rather than measuring bankruptcy stigma through the examination of indirect bankruptcy stigma proxies or through the questioning of former petitioners, this study measures evolving public perceptions about bankruptcy by examining the expressed sentiments of the general public. To ascertain whether the negative image of bankrupts has eroded in the United States over the past century and a half, 171 newspaper articles published between 1364 and 2002 about personal bankruptcy were examined for content. Examination of the content of personal bankruptcy related newspaper articles provides valuable information about the evolution of public perceptions of bankrupts during that period. This study detected a noticeable shift, beginning in the 1960s, in public attitudes towards individuals filing.for personal bankruptcy. However, it did not find that the changing public perception necessarily prompted an increase in the bankruptcy flings.

\section{INTRODUCTION}

Historically, individuals who file for bankruptcy protection have been viewed harshly by society. The negative perception of bankrupts was manifested in the punitive treatment of them, which included at times forfeiture of all property, relinquishment of spousal consortium, revocation of citizenship, surrendering children as slaves, prohibition from holding public office, imprisonment, and death.' Aside from these severe punishments, bankruptcy petitioners were routinely degraded and humiliated in public. At times, bankrupts were forced to sit in public and place baskets over their heads. In other instances, they were required to bang their buttocks on a rock before a heckling crowd, or wear distinguishing clothes in public, or simply be sold at a public auction to the highest bidder. ${ }^{2}$ Degradation and humiliation of bankrupts were reinforced through official contemptuous discourse, which labeled bankrupts as "deceivers," "frauds," "offenders," "cheaters," and "squanderers." "3

This traditional negative image of bankrupts was similarly held in colonial America, and vigorously continued throughout the Victorian era and into the 20th century. By the 1960s, a number of critics had begun to voice

See infra notes 29-40 and accompanying text.

2 See infra notes 12-18 and accompanying text.

3 See infra notes 19-24 and accompanying text. 
their concerns about the dramatic rise in consumer bankruptcy filings in the United States. The critics mostly attributed the increase in filings to an alleged decline both in morals and in the shame associated with bankruptcy. While the stigma of bankruptcy exists to this day, charges of the fading stigma of bankruptcy have recently intensified. A number of recent studies have attempted to corroborate assertions of the declining stigma of bankruptcy through the use of indirect variables such as proxies. These attempts have been roundly criticized. The disapproval centers mainly on the studies' failure to directly measure changes in public perception of bankruptcy.

This study attempts to measure the evolution of stigma in bankruptcy by addressing the methodological concerns attributed to previous empirical studies on this subject. Rather than measuring bankruptcy stigma through the examination of indirect bankruptcy stigma proxies, or through the questioning of former petitioners, this study measures evolving public perception of bankruptcy by directly examining the general public's expressed sentiments.

This Article will begin with an examination of historical social norms regarding the bankrupt, both globally and in the United States. Given the persistent historical and contemporary manifestations of stigma in bankruptcy, Part I will attempt to address the question of why stigma is attached to bankruptcy. Part II will describe the methodology of this study in measuring the evolution of public perception about personal bankruptcy. The Article will conclude with a discussion of the results of this study.

\section{The Evolution of Stigma in Bankruptcy}

\section{A. The Evolution of Bankruptcy Stigma Outside the United States}

Historically, heavy stigma was closely associated with individuals who were declared bankrupt. ${ }^{4}$ The stigma arose since the debtor's conduct, leading up to the declaration of bankruptcy, was deemed to deviate from

4 See, e.g., W.J. Jones, The Foundations of English Bankruptcy: Statutes and Commission in the Early Modern Period 53 (1979) (suggesting that during the 17th century, bankrupts in England "were considered by some as worse than highway robbers and more damaging than foreign enemies"); Barbara Weiss, The Hell of the English: Bankruptcy and the Victorian Novel 35 (1986) ("It is clear from such statements that bankruptcy was considered [during the Victorian era in England] a shameful condition, worthy of the harshest language."); M.S. Servian, Eighteenth Century Bankruptcy Law: From Crime to Process 38 (1985) (unpublished Ph.D. 
traditionally accepted social moral norms. ${ }^{5}$ First, while traditional moral norins demanded that an individual act honestly towards all other members of society, bankruptcy filings were deemed either as fraudulent conduct on the part of the debtor toward his creditors, ${ }^{6}$ or as a reckless disregard of the debtor's moral obligation to repay her debts to the trusting creditors. ${ }^{7}$ Second, bankruptcy filing was deemed morally deviant because undertaking personal

dissertation, University of Kent at Canterbury) (on file with author) ("'Bankruptcy" laws have virtually universally carried with them social stigmatization for the bankrupt."); Adam Smith, An Inguiry into the Nature and Causes of the Wealth of Nations, reprinted in 39 Great Books of the Western World 1, 148 (Robert M. Hutchins ed., 1952) ("Bankruptcy is perhaps the greatest and most humiliating calamity which can befall an innocent man. The great part of men, therefore, are sufficiently careful to avoid it. Some, indeed, do not avoid it; as some do not avoid the gallows."); James Q. Whitman, The Moral Menace of Roman Law and the Making of Commerce: Some Dutch Evidence, 105 Yale L.J. 1841, 1871 (1996) ("To European authors everywhere in the seventeenth century, the declaration of bankruptcy was the single most scandalous phenomenon of commercial society ... all of whom regarded the declaration of bankruptcy as a ghastly evil."); id. at 1876 (quoting a German pamphleteer of 1619 describing the reaction in the community of a bankruptcy filing as follows: "Once word of this makes the rounds and becomes known, the average man bursts out with imprudent, violent and angry words. He storms, curses, blasphemes, says scandalous and contemptuous things about debtors, denouncing them as rogues, thieves and men without honor ....").

5 See. e.g., Weiss, supra note 4, at 29 (1986) ("There is no denying the sincerity of the Victorians' moral outrage toward bankruptcy.").

6 For example, during the seventeenth century in France, the term "bankrupts" referred only to fraudulent debtors. See 2 George J. Bell, Commentaries on the Law of Scotland and on the Principles of Mercantile Jurisprudence 471 (7th ed. 1868). Similarly, certain segments of the commercial society in medieval Italy formally referred to bankrupts as deceivers and frauds. See Bolkmar Gessner et al., Three Functions of Bankruptcy Law: The West German C'ase, 12 L. \& Soc'y Rev. 499, 531 (1978). Lastly, the Bankruptcy Act in England in the early 18th century was titled "An Act to Prevent Frauds Frequently Committed by Bankrupts," 1705, 4 Ann., c. 17 (Eng.). The introductory statement to the Act explains that "bankruptcy was caused not so much by reasons of losses and unavoidable misfortunes, but rather by an intent to defraud and hinder [creditors] of their just debts ...." See also Jay Cohen, The History of Imprisonment for Debt and IIs Relation to the Development of Discharge in Bankruptcy, 3 J. Legal Hist. 153, 157 (1982).

7 The debtor's violation of the debtor-creditor trust relationship was deemed a violation of social norms because it was viewed as a betrayal of an almost sacred relationship. See Lisa J. Mclntyre, A Sociological Perspective on Bankruptcy, 65 lnd. L.J. 123, 136 (1989) ("Bankruptcy is an indication that one has betrayed (or is betraying) a trust that is judged to be important by many. Thus, the debtor contemplating bankruptcy anticipates that betrayal of this trust will lead to a shared outrage and stigma."); Servian, supra note 4, at 23 ("Judges [in England] saw bankrupts as posing a threat to the very fabric of their contemporary social order: credit was 
credit was viewed as immoral. ${ }^{8}$ That is, bankruptcy filing suggested that the debtor had failed to responsibly manage her personal financial affairs by not living within her means, and instead choosing to consume credit.'

In an attempt to voice their disapproval of the deviancy associated with personal bankruptcy and to reinforce the stigma associated with bankruptcy, societies historically adopted bankruptcy laws that emphasized the bankrupt's deceitful, quasi-criminal conduct in entering into bankruptcy, focusing on degrading the bankrupt, and imposing significant penalties on the bankrupt. The laws' emphasis on the bankrupt's deceitful, quasicriminal conduct was reflected in the typical statutory requirements for commencing bankruptcy. Whereas contemporarily the vast majority of bankruptcy petitions are voluntarily filed by the petitioner, originally, commencement of bankruptcy was involuntary. ${ }^{10}$ Furthermore, whereas today bankruptcy is available to non-f raudulent debtors, traditionally to force an individual into bankruptcy, her creditors were required to demonstrate that the debtor had engaged in one of several "acts of bankruptcy." Acts of bankruptcy included fraudulent conduct of the debtor or concealment of assets. ${ }^{\prime 1}$ Hence, by linking fraudulent conduct with the commencement of bankruptcy, the bankrupt automatically earned the disrespect of society.

widespread in 18 th century society, and someone who became insolvent posed a direct threat to the stability of that system.").

8 For example, in 18th century England, the public held a restrictive view of personal credit, "for the law holds it to be unjustifiable practice for any person but a trader to encumber himself with debts of any considerable value." 2 William Blackstone, Commentaries on the Laws of England *473-74.

9 See G. Crompton, Practice Common-Placed: Or, the Rules and Cases of Practice in the Courts of King's Bench and Common Pleas, at xix (3d ed. 1786) (As one commentator on 18th century English law stated: "If persons in other stations of life [non-traders] will run into debt without the power of judgment, the legislature has wisely left them to take the consequences of their own indiscretion.").

10 See Charles J. Tabb, The Historical Evolution of the Bankruptcy Discharge, $65 \mathrm{Am}$. Bankr. L.J. 325, 330 (1991) ("Under this act (and almost three centuries hence) bankruptcy [in England] was purely involuntary as to the debtor."). See also Vern Countryman, Bankrupicy and the Individual Debtor and a Modest Proposal 10 Return to the Seventeenth Century, 32 Cath. U. L. Rev. 809, 811 (1983).

11 See Peter J. Coleman, Debtors and Creditors in America: Insolvency, Imprisonment for Debt, and Bankruptcy, 1607-1900, at 269-70 (1974) ("Bankruptcy was a legal status, a condition arrived at by committing a proscribed act, such as concealing property from lenders, absconding, or transferring assets with fraudulent intent."); Weiss, supra note 4, at 35: "[T]his 'terror' on the part of respectable businessmen at the name of 'bankrupt' may be explained by the criminal origins of the laws of bankruptcy. ... The criminal origins of bankruptcy law were very likely one reason for the social disgrace that attached to it." 
In addition to the emphasis on the debtor's malicious pre-petition conduct, many of the bankruptcy or debt collection systems were intentionally degrading and humiliating towards the debtor. In ancient India, for example, unpaid creditors would sit and fast on the debtor's doorstep. As the starving creditor would reach exhaustion, the masses would join the creditor's sit-in and demand repayment. ${ }^{2}$ In Ancient Greece, bankruptcy laws forced the debtor to sit in the market place and place a basket over his head. ${ }^{13}$ In Ancient Rome, the insolvent debtor's body was auctioned off for sale in the middle of the commercial center in town. ${ }^{14}$ In pre-modern Italy, insolvent debtors were brought naked to a public square where they were required to bang their buttocks on a specially designated rock before a heckling crowd. ${ }^{15}$ During the 17th century in Scotland, bankrupts were required to wear a distinctive coat and cap, half yellow and half brown, in public. ${ }^{16}$ Similarly, in France, the bankrupt was carried to the center of the market place where commencement of his bankruptcy was publicly announced. Further, to avoid immediate imprisonment, the bankrupt was ordered to regularly wear a green bonnet. ${ }^{17}$ When bankrupts appeared before a judge, they were required to expose their naked bodies. ${ }^{18}$ These publicly humiliating rules and practices served to both manif est and reinf orce the already embedded stigma associated with bankruptcy.

Another way by which legislators traditionally degraded the bankrupt was through labeling. The common contemporary usage of the label "bankrupt" carries with it a strong adverse social connotation. ${ }^{\prime 9}$ This negative

12 See George Sullivan, The Boom in Going Bust: The Threat of a National Scandal in Consumer Bankruptcy 24 (1968).

13 See Serviaul, supra note 4, at 38 ("[According to the ancient Boetian bankruptcy code], the Boetians caused their bankrupts to be disgraced by forcing them to sit in the market place with a basket on their heads.").

14 I S. Scott, The Civil Law 63-64 (1932).

15 Whitman, supra note 4, at 1873.

16 Bell, supra note 6, at 472.

17 Id. at 471.

18 See Whitman, supra note 4, at 1875 (to reinf orce public conf ormation and humiliation of the bankruptcy petitioner, in 1490, French law mandated that petitioners appear bef ore a judge "bare-headed and with their clothing hanging open [to expose their naked bodies] to mark and augment their infamy").

19 See lan F. Fletcher, The Law of Insolvency 33 (Ist ed. 1990) ("In everyday usage, the terms 'bankruptcy' and 'bankrupt' carry heavy connotations of personal disaster accompanied by social stigma, giving rise to the supposition that bankruptcy is a fate to be avoided at all costs."). The adverse connotation of the word "bankrupt" has been in existence for a long time. See Israel Treiman, Acts of Bankruptcy: Medieval Concept in Modern Bankruptcy Law, 52 Harv. L. Rev. 189, 189 (1938) 
connotation is largely a product of the traditional usage of the term. In medieval Italy, society commonly referred to bankrupts as "deceivers and frauds." ${ }^{20}$ During the 16th century in England, bankruptcy law repeatedly ref erred to bankrupts as "of fenders." ${ }^{12}$ These associations between bankrupts and criminals fostered the stigmatization of bankrupts, which still exists today. ${ }^{22}$ Sim ilarly, the words used in France to ref er to bankruptcy petitioners suggest a strong contempt towards bankrupts. The word "Bankqueroute" in French is based on the Latin word fallere, which means "to cheat, deceive, or trick." 23 Likewise, individuals who are unable to pay their debts in bankruptcy are referred to in French as "deconfiture," figuratively meaning "to squander." ${ }^{24}$

Apparently, communities' cohesiveness made it possible for these publicly humiliating and labeling practices to be powerful in generating deep fear of bankruptcy in the minds of the people, ${ }^{25}$ as well as public censorship and ostracism of bankrupts. ${ }^{26}$ The length of the excommunication period for the bankrupt generally lasted at least until the conclusion of the bankruptcy

("Even without the disgrace implied in the very etymology of the term banknupt, undiscriminating condemnation of the debtor who fails to meet his obligations will probably continue as long as human nature is what it is.").

20 See Gessner, supra note 6, at 53 1.

21 See Fletcher, supra note 19, at 6; Servian, supra note 4, at 21.

22 Fletcher, supra note 19, at 6 ("The repeated references in the statute to absconding debtors as 'offenders' signifies the close identification between bankruptcy and criminality at this period, a stigma which was to endure until relatively recent times and one which has not yet been totally relinquished.").

23 See Daniel Desurvire, Histoire De La Bankqueroute et Faillite Contemporaine II (1992). "Bankqueroute" in French refers to debtors on the road who departed without paying their debts and lived off their illicit gains. See Joseph Pomykala, Bankruptcy Reform: Principles and Guidelines, 20 Regulation, Fall 1997, at http://www.cato.org/pubs/regulation/reg20n4g.pdf.

24 See Pascal Ancel, Droit Des Suretes 2-3 (2d ed. 2000); J.H. Dalhuisen, Dalhuisen on International Insolvency and Bankruptcy, Sec. 3.02[1] (1983).

25 One king described his feeling toward bankruptcy stigma as follows: "The stigma of bankruptcy has always terrified me." Servian, supra note 4 , at 229 . In the 17 th century, Shakespeare referred to a bankrupt individual as "a prodigal who dare scarce show his face at the Rialto." William Shakespeare, The Merchant of Venice act 3 , sc. 1 , cited in Servian, supra note 4 , at 38 .

26 See Servian, supro note 4, at 229 (a bankrupt individual is stripped of his status and is separated from his community). 
process. ${ }^{27}$ The excommunication severely limited the bankrupt's ability to participate in both social and economic aspects of society. ${ }^{28}$

A final historical statutory manifestation of the negative perception of bankrupts held by societies can be observed in the draconian penalties and discrimination inflicted on insolvent individuals. Historically, penalties imposed on defaulting debtors included forfeiture of all property, relinquishment of the consortium of a spouse, imprisonment, and death.29 In the ancient bankruptcy code of India, creditors were first allowed to remove a hand, then an eye of a bankrupt before killing him. ${ }^{30}$ Similarly, in the ancient Egyptian code, creditors were allowed to "pawn the embalmed bodies of the dead [debtors] for money. ${ }^{131}$ In Ancient Greece, debtors had to surrender their children to be exported as slaves, and debtors had to forfeit their citizenship. ${ }^{32}$ In addition, creditors in Ancient Greece were allowed to seize and retain the bodies of deceased defaulters until the debt

27 "Till [the bankrupt] has gained [his certificate] he is separated from the community he has wronged." $/ d$. at 222. In England, the period during which a bankrupt could remain in the bankruptcy process without getting a discharge was sometimes indefinite. This observation was made by a British bankruptcy reform committee in 1982. It found that "[p]rior to the Insolvency Act of 1976 [in England] the onus had been on the bankrupt to apply to the court for discharge. Many did not do so, either through ignorance of the procedure or reluctance to attend open court and thus to attract further publicity." Sir Kenneth Cork, Insolvency Law and Practice: Report of the Review Committee 142 (1982). A similar phenomenon was reported in Israel. See Philip Shuchman, Field Observations and Archival Data On Lxecution Process and Bankruptcy in Jerusalem, 52 Am. Bankr. L.J. 341, 364 (1978). The author found that many bankruptcy petitions in Israel remained open but inactive for many years. The fact that many cases simply remain open for years, with no activity and with no discharge, demonstrates that debtors either do not apply for discharge altogether, or do apply and are denied. In the Jewish tradition, formal ostracism of defaulting debtors was not generally practiced. However, during the I I th Century, some communities placed a ninety day ban against any debtor who failed to repay his debts, unless the debtor was able to demonstrate that he did not have the means to do so. See Menachem Elon, Freedom of the Debtor's Person in Jewish Law 38-49 (1964).

28 See Servian, supra note 4, at 222 ("As we know, the swindler/undischarged bankrupt was outlawed from the merchant community both by his inability to receive or to earn money for himself, and by the immense stigma attached to his being an undischarged bankrupt.").

29 See Charles J. Tabb, The History of the Bankruplcy Lans in the Lniled States, 3 Am. Bankr. Inst. L. Rev. 5,7 (1995).

30 See Servian, supra note 4 , at 42 .

31 See id.

32 See Sullivan, supra note 12, at 24-5. 
was paid. ${ }^{33}$ In Ancient Rome, a creditor was allowed to privately imprison his defaulting debtor. If the debtor remained unable to pay, the creditor was permitted to sell the debtor into slavery. In cases of multiple creditors, Rome's Twelve Tables authorized the creditors to carve up the body of the debtor as a symbolic way of obtaining repayment. ${ }^{34}$ In Germany, the Hamburg Bankruptcy Acts of 1630 and 1753 imposed the threat of expropriation and imprisonment against some bankrupts. ${ }^{35}$ The British Bankruptcy Acts of 1604 and 1623 provided that certain bankrupts be pilloried and lose an ear. ${ }^{36}$ Further reflective of the punitive nature of bankruptcy in England, the Bankruptcy Act of 1705 offered the death penalty for fraudulent bankrupts, ${ }^{37}$ until an 1820 enactment replaced death with imprisonment. ${ }^{38}$ During the 19 th Century, bankrupts in France were not allowed to hold public office, sit on juries, practice as stockbrokers, or appear before the Bourse until they had paid their debts in full. Similarly, in Germany at that time, bankrupts could not vote or hold seats in the parliament. ${ }^{39}$ While the draconian penalties related

33 See Barbara A. Mathews, Forgive Us Our Debts: Bankruptcy \& Insolvency in America, 1763-1841, at 9 (1994) (unpublished Ph.D. dissertation, Brown University).

34 See id.; Tabb, supra note 29, at 7; J. N. Funceius, Leges XII Tabularum, fragmentis restitutæ et illustratæ (1744).

35 See Gessner, supra note 6, at 532-33.

36 See also lau P.H. Duffy, English Bankrupts. 1571-1861, 29 Am. J. Legal Hist. 283, 284-85 (1980); Tabb, supra note 10, at 330, 332 n.41.

37 Bankruptcy Act, 1705, 4 Anne, c. 17 (Eng.); See Fletcher, supra note 19, at 8; Duffy, supra note 36, at 287.

38 Bankruptcy Act, 1820, 1 Geo. 4, c. 115 (Eng.); See Joseph Pomykala, Bankruptcy's Origins in Debtor Perpetrated Crime 4 (Oct. 2000) (unpublished manuscript, on tile with author) ("Debtors convicted of bankruptcy in England could be hanged until an 1820 enactment substituted seven years, with or without hard labor, for the death penalty."); Tabb, supra note 29, at 7 ("Early English law had a distinctly pro-creditor orientation, and was noteworthy for its harsh treatment of defaulting debtors. Imprisonment for debt was the order of the day ...."). The popularity of imprisonment for defaulting debtors was alluded to by a seventeenth century English jurist, Sir Robert H. Hyde, who stated that:

If a man be taken in execution, and lie in prison for debt, neither the plaintiff, at whose suit he is arrested, nor the sheriff who took him, is bound to find him meat, drink, or clothes; but he must live on his own, or on the charity of others; and if no man will relieve him, let him die in the name of God, says the law; and so say 1.

James L. Bishop, A Treatise on the Common and Statute Law of the State of New York Relating to Insolvent Debtors 4 (3d ed. 1895) (quoting Sir Robert H. Hyde).

39 See Pomykala, supra note 38 , at 5. 
to bankruptcy have largely disappeared in the modern world, many countries still regularly impose significant penalties on bankrupts. ${ }^{40}$

These degrading and punitive bankruptcy laws reflected the prevailing negative sentiments of society towards bankrupts, and served to reinforce and perpetuate the social stigma associated with bankruptcy. ${ }^{41}$

\section{B. The Evolution of Bankruptcy Stigma in the United States}

The traditional negative image of bankrupts was similarly present in colonial America. ${ }^{42}$ Insolvent debtors were perceived as criminals and thieves, ${ }^{43}$ but mostly as slaves and dependents. ${ }^{44}$ This harsh view of the defaulting debtor was manifested in the formal imposition of unforgiving penalties, including imprisonment and flogging. ${ }^{45}$ Furthermore, the closely bound and cohesive communities during the colonial period facilitated the imposition of

40 See Rafael Efrat, Clobal Trends in Personal Bankruplcy, 76 Am. Bankr. L.J. 81, 83, 89-90 (2002) (describing penalties imposed on bankrupts in Italy, England, and Canada).

41 See Gessner, supra note 6, at 532 ("[T] of bankruptcy, .. . carried a moral stigma and social disqualifications.").

42 During the initial years of colonization, most statutes were rather favorable towards debtors. However, this sympathetic attitude soon disappeared. See Coleman, supra note 11 , at 249 .

43 See Edward Channing, A History of the United States 184 (1921) ("the non-payment of debt . . . was looked upon as practically the equivalent of theft.").

44 See 7 Benjamin Franklin, The Papers of Benjamin Franklin 342-49 (Leonard W. Labaree ed., 1963):

Think what you do when you run in Debt; You give to another Power over your liberty... . The Borrower is a Sale to the Lender, and the Debtor to the Creditor, disdain the Chain, preserve your Freedom, and maintain your independency: $\mathrm{Be}$ industrious and free; be frugal and free.

See also Bruce H. Mann, Republic of Debtors: Bankruptcy in the Age of American Independence 130-31 (2002) ("The image of debtors as slaves was a common one before the Revolution. . . ."); id. at 145 ("the imagery of insolvency was dependence"); Scott A. Sandage, Deadbeats, Drunkards, and Dreamers: A Cultural History of Failure in America, 1819-1893, at 115-217 (1995) (unpublished Ph.D. dissertation, Rutgers Univeristy) (on file with Rutgers University Libraiy) (documenting pervasive use of the slavery metaphor in bankruptcy debates from 1820 to 1867).

45 See Coleman, supra note 11 , at 249 (remarking that by the close of the 17th century, debtor's prison was widespread in the American colony); Mann, supra note 44, at 79 ("The only consistency among debt laws in the 18th century was that every colony, and later every state, permitted imprisonment for debt ...."); Sullivas,, supra note 12, at 29 (in the years that followed the American revolution, "more people were imprisoned for debt than for any other reason"); Thomas E. Plank, The 
various stern shaming practices directed at insolvent debtors. ${ }^{46}$ For example, to disgrace the bankrupt, the bankrupt's hair would be cut off. ${ }^{47}$ Also, the debtor's palm would be branded with the letter " $T$ " for "thief" and he would be mandated to stand in a public square for two hours with an ear nailed to the pillory and then cut off. ${ }^{48}$

While debtor's prison had become somewhat less popular during the 19 th century, ${ }^{49}$ bankruptcy related stigmas persisted with full force during that time ${ }^{50}$ Bankruptcy continued to be viewed by most as a crime, and much of the Victorian era culture revolved around the humiliation associated with debtors' def au It. ${ }^{51}$

Bankruptcy's stigma remained pervasive during the first half of the 20th century. Congressional testimony and law professors' writing provide some anecdotal evidence of its pervasiveness during that time. ${ }^{52}$ One report to the President of the United States issued by the Attorney General in 1932 reinforced these sentiments, asserting that many financially troubled individuals avoid bankruptcy filing "until all their assets are gone to avoid the

Constitutional limils of Bankruplcy, 63 Tenn. L. Rev. 487, 518 (1996) (asserting that during the colonial period, debtor's prison was pervasive).

46 See Lawrence M. Friedman, Crime \& Punishment in American History 37 (1993) (noting that shaming practices were routinely used in the small town and intimate communities during the colonial period); Toni M. Massaro, Shame, Culnure, and American Criminal Law, 89 Mich. L. Rev. 1880, 1915 (1991) ("the white colonists lived in intimate, closely bound, and normatively cohesive communities, with in which shaming could and did play a signal role in reinforcing standards of behavior.").

47 Pomykala, supra note 38 , at 4 n.2.

48 See Joseph S. Pomykala, Bankruptcy Lavis: The Need for Reform, in Legal Environment of Business 178, 180 (Kurt Stanberry ed., 2000).

49 See Edward J. Balleisen, Navigating Failure: Bankruptcy and Commercial Society in Antebellum America 12 (2001) ("beginning in the 1820s, the use of the debtor's prison in the United States began to decline, with several states limiting imprisonment to instances of fraud"); Mathews, supra note 33, at 207 (describing the trend during the 19th century in a number of states of beginning to dismantle the institution of debtor's prison).

50 See. e.g., In re Gibraltor Amusements, Ltd., 29l F.2d 22, 27 (2d Cir. 1961) (alluding to the vigor of bankruptcy stigma during the 19th century).

51 See Marcus Cole, A modest Proposal for Bankruptcy Reform, 5 Green Bag 2d 269, 273 (2002).

52 See In re Lawrence Products Company, Inc., 211 F. Supp. 301, 305 (1962) ("During the authorship of the Chandler Act [of 1938], many advocated the complete divorcement of Chapters X, XI, XII, and XIII from the Bankruptcy Act to avoid the stigma of bankruptcy."); Treiman, supra note 19, at 189 (asserting that bankruptcy stigma is as strong as it used to be during the 17th century). 
stigma of bankruptcy. ${ }^{153}$ Nonetheless, as debtor's prison had come to an end in most states by the 1920s, and as the number of consumer bankruptcies began to rise during the $1920 \mathrm{~s},{ }^{54}$ both the Solicitor General and the Department of Commerce declared soon thereafter that the stigma traditionally associated with bankruptcy was beginning to decline. ${ }^{55}$

By the 1960s, a number of critics had begun to voice their concerns about the dramatic rise in consumer bankruptcy filings. The critics from Congress, the mass media, the Bar, and academia attributed the increase in filings mostly to an alleged decline in morals and shame associated with bankruptcy. ${ }^{56}$ These allegations were made despite a number of contemporaneous studies that pointed out that bankruptcy stigma remained robust among the vast

53 See Message from the President of the United States Recommending the Strengthening of Procedure in the Judicial System Together with the Report of the Attorney General on Bankruptcy Law and Practice, S. Doc. No. 65 (1932).

54 See Thomas D. Thacher, Administration of the Bankruptcy Act, Report of the Fifty-Third Annual Meeting of the American Bar Association Held in Chicago, Illinois, August 20, 21, \& 22, 1930, at 251, 255 (1930) (referring to a sharp increase in the number of consumer bankruptcy filings during the 1920s); Catherine L. Kruchen, Casenote, Domestic Relations - Support of Stepchildren-Obligation 10 Support Stepchild Held to be a Debt, Not a legal Duty: and There fore Step-parent's Contempt of Court for Default in Support Payments Cannol be Punished by Imprisonmen -Brown v. Brown, 287 Md. 273. 412 A.2nd 396 (1980), 10 U. Balt. L. Rev. 190, 193 (1980) (indicating that by the 1920s, most states had abolished imprisonment for debt except for limited circumstances).

55 See Victor Sadd \& Robert T. Williams, U.S. Dep't of Commerce, Causes of Bankruptcies Among Consumers 8 (1933) (suggesting that bankruptcy stiguna has been declining in recent years); Thacher, supra note 54, at 251, 255 (the Solicitor General of the United States blaming the rise in consumer bankruptcies during the 1920 s on the decline of bankruptcy stigma).

56 See Wage Earner Plans Lnder the Bankruptcy Act: Hearing on H.R. 1057 and H.R. $577 /$ Before the House Comm. On the Judiciary, 90th Cong. 3 (1967):

Consumer bankruptcy in the United States is beginning to assume alarming proportions. ... As a percentage of total bankruptcies, the figures are even more dramatic. In 1940, the figure was $25 \%$, in 1966 , it was $91 \%$. . . No, it is not the growth of installment sales which deserves the indictment. . . It belongs, too, with changes that have taken place in society's attitudes about principles, values and priorities.

Sullivan, supra note 12, at 9:

It wasn't many years ago that bankruptcy was regarded as a fairly wicked way to wash out one's indebtedness. Any man who went bankrupt was treated almost as a leper. Women filed about as often as they swain the English Channel. Bankruptcy had a stigma attached to it. It still does, but the scar it leaves isn't nearly so deep as it used to be. 
majority of Americans. ${ }^{57}$ A Supreme Court decision during the 1960s seems to confirm the results of these studies suggesting that the bankruptcy stigma was as present as ever. ${ }^{58}$

The stigma of bankruptcy has persisted to some extent over the past forty years. A formal report to Congress from the early 1970s declared that consumer debtors were steered away from pursuing bankruptcy relief because of the entrenched stigma associated with the process. ${ }^{59}$ In

Fred C. Fields, Needed Changes in Individual Bankruptcy, Proceedings of Oklahoma Institure of Consumer Credit Management for 1959, in George A. Brunner, Personal Bankruptcies: Trends and Characteristics 4, 7 (1965), opines that the increase in bankruptcy filings by individuals is attributed to

a change in the attitude of the public which condoned bankruptcy ... that individual bankruptcy was not a disgrace, but just a smart business tactic . . . . Debtors were taught to take the easy way out. The moral courage which had so long been dominant in our wage earners began to deteriorate.

G. Stanley Joslin, The Philosophy of Bankruplcy - A Re-Eramination, 17 U. Fla. L. Rev. 189, 192 (1964) ("while one may become somewhat stigmatized as a result of bearing the label of a bankrupt, this stigma is becoming of diminishing social importance").

57 See Herbert Jacob, Debtors in Court: The Consumption of Government Services II 3 (1969) (reporting on a US Gallup Poll conducted for the Brookings Institution in 1966 which revealed that fifty-five percent would refuse or hesitate to do business with someone who had gone bankrupt while forty-two percent thought their friends and co-workers would think badly of them if they went bankrupt); David T. Stanley \& Marjorie Girth, Bankruptcy: Problem, Process, Reform 231 (1971) (reporting the findings of a survey of 1,523 interviewees to the following question: "Suppose you, yourself, got into a very difficult financial situation - how would you feel about going bankrupt?" Of the more than $75 \%$ who would not go bankrupt, $20 \%$ would not go bankrupt under any circumstances, 33\% would go bankrupt only as a last resort, 18\% would feel disgraced if they did, and 5\% could not conceive of going bankrupt); Milton J. Huber, A Study of Financially Over-Extended Families 28-29 (1965) (unpublished manuscript, on file with author) (reporting that a sizeable percentage of financially troubled individuals, who opted not to file for bankruptcy, had declined bankruptcy "on grounds of morality and pride"); William J. Preston, A Comparison of the Rationale and Socio-Economic Characteristics of Straight Bankruptcy and Chapter XIII Petitioners in the Denver, Colorado, Area 133 (1969) (unpublished Ph.D. dissertation, Colorado State College) (on file with the Colorado State College Library) (reporting on an interview with a bankrupt who had asked his college age sister to leave the room where the interview was taking place as the petitioner did not want his sister to find out about his bankruptcy filing).

58 See Perry v. Commerce Loanl Co., 383 U.S. 392, 395 (1965) ("In [straight bankruptcy] proceedings, everyone lost - the creditors by receiving a mere fraction of their claims, the debtor by bearing thereafter the stigma of having been adjudged a bankrupt.").

59 See Report of the Commission on the Bankruptcy Laws of the United States, H.R. Doc. No. 93-137, Pt. 1 (1973); id. at 15 ("The preponderant majority of debtors 
recognition of the deterrent impact of the stigma on bankruptcy filing, in the late 1970s Congress aimed at crafting a more attractive repayment chapter to the bankruptcy code as a way of alleviating "many debtors" desire to avoid the stigma attached to straight bankruptcy."160

Aside from Congressional recognition of the stigma of bankruptcy, public polls during the 1980s and 1990s suggested that the majority of the population would be hesitant to vote into office or do business with anyone who had filed for bankruptcy. ${ }^{61}$ Another survey in 1993 found that more than three fourths of former bankruptcy petitioners who were interviewed described their feelings about their bankruptcy filing as "just terrible."62 Furthermore, writings from academia and the mass media emphasized the shame and embarrassment associated with bankruptcy filing. ${ }^{63}$ Moreover, a number of published legal opinions tended to confirm that some judges find bankruptcy stigma to be persistent and real. ${ }^{64}$

However, perhaps the most profound manifestations of bankruptcy stigma

desire some means of paying their debts in preference to incurring the stigma and other consequences of bankruptcy.").

60 H.R. Rep. No. 95-595, at 118, reprinted in 5 U.S.C.C.A.N. 5787, 6078-79 (1978).

61 See Howard W. Odum Institute for Research in Social Science, California Field Poll, available al http://cgi.irss.unc.edu'tempdocs/ (Oct. 1982) (finding that $53 \%$ of Californians polled would not have voted into public office aslyone who had filed for bankruptcy); The Roper Center at the University of Connecticut, Public Opinion Online 1, available at http://www.ropercenter.uconn.edu/ (May 7, 1991) (reporting the findings of an opinion poll that $55 \%$ of the 909 adults surveyed by phone indicated that they would not do business or would be reluctant to do business with a former bankruptcy petitioner).

62 See The Roper Center at the University of Connecticut, Public Opinion Online I, available al http://wivw.ropercenter.uconn.edu/ (Nov. 6, 1993).

63 See David Caplowitz, Consumers in Trouble: A Study of Debtors in Default 274 (1974) ("Since shame is attached to bankruptcy, many who are eligible for this relief do not seek it, and those who do are likely to pay immeasurable psychological costs."); Kathy R. Davis, Bankruptcy: A Moral Dilemma for Women Debtors, $22 \mathrm{~L}$. \& Psychol. Rev. 235, 239 (1998) ("Even though the bankruptcy laws have changed, the stigmatization of filing for bankruptcy and the moral aversion to it remains."); Philip Shuchman, An Attempt at a "Philosophy of Bankruptcy," 21 UCLA L. Rev. 403,416 (1973) ("Straight bankruptcy is degrading or at least tends to reduce the bankrupt's self-esteem or harm his conception of himself."); Michelle .l. White, Why Dont More Households File for Bankrupıcy?, 14 J.L. Econ. \& Org. 205 (1998) (suggesting that the dramatic disparity between the number of households that actually file for bankruptcy and the number of households that could benefit from filing for bankruptcy may be explained by the presence of stigma that keeps households from filing).

64 See In re Walton, 866 F.2d 981, 987 (8th Cir. 1989) (McMillian, J., dissenting) ("After all, no one really wants to be bankrupt and it is only after financial disaster 
were the reported instances in which a bankrupt petitioned the court to have his name changed or to have the bankruptcy petition dismissed altogether to avoid the perceived stigma. ${ }^{65}$ More dramatic yet are the results of a General Social Survey during the last thirty years that reported an appreciable number of respondents believing that bankruptcy is an acceptable reason for committing suicide. ${ }^{66}$ Stigma has also been manifested through the anecdotal evidence of embarrassed bankrupts desperately searching for ways to conceal their bankruptcy filing from others. ${ }^{67}$ Lastly, a recent study has suggested that

strikes that anyone would seek to give up and be branded with the stigma of bankruptcy."); In re Raymond, 12 Bankr. 906, 907 (Bankr. E.D. Va. 1981):

Bankruptcy is a serious step; it holds its stigmas still. It is a unique judicial process where one is laid bare, financially. And remember this - it results in a court record for future employers, creditors, friends, relatives and the public to see. Would you grant a security clearance to one who cannot manage his financial affairs and files bankruptcy?

Freeman v. State, 767 P.2d 1354, 1357 (Okla. Crim. App. 1988) (finding bankruptcy stigma to be substantial, the court precluded the introduction of the defendant's prior bankruptcy filing as evidence during trial "because its probative value is substantially outweighed by its prejudicial effect"). But see Bankruptcy - No Longer a Dirty Word, U.S. News \& World Report, Apr. 7, 1975, at 52 ("The stigma once attached to taking a financial bath no longer seems to be an important consideration for many modern-day debtors, according to judges in bankruptcy courts across the country.").

65 See, e.g., In re Komyathy, 142 B.R. 755, 756 (Bankr. E.D. Va. 1992) (debtor asking the court to dismiss her voluntary chapter 7 petition on the grounds that she wishes to avoid the stigma of bankruptcy); In re Martin, 30 Bankr. 24, 26 (Bankr. E.D.N.C. 1983); In re Blue, 4 Bankr. 580, 582 (Bankr. D. Md. 1980) (the debtors in this case sought to dismiss their petition two and a half months after filing in order to avoid the stigma of bankruptcy); In re Stempler, 441 N.Y.S.2d 800 (1981) (granting a request to change a person's name where the petitioner, who had filed a voluntary petition of bankruptcy 16 years ago, wished to avoid the stigma of the prior bankruptcy adjudication).

66 See The National Opinion Research Center, General Social Survey 1972-2000 Cumulative Codebook, available at http://webapp.icpsr.umich.edu/GSS/ (last visited Jan. 12, 2004) (reporting that $4.4 \%$ to $9.6 \%$ of the respondents find that bankruptcy filing is an acceptable reason to end one's life).

67 See Teresa A. Sullivan, Elizabeth Warren \& Jay Lawrence Westbrook, The Fragile Middle Class: Americans in Debt 32 (2000) [Hereinafter Fragile Middle Class] ("Public identification as a bankrupt debtor is embarrassing at best, devastating at worst. Bankrupt debtors have told us of their efforts to conceal their bankruptcy."); $i d$. at 139 (reporting on bankruptcy stories that reveal "self-loathing and humiliation in recognition of what [bankrupts'] spending habits have brought them to"); Jean Braucher, Lawyers and Consumer Bankruptcy: One Code, Many Cultures, 67 Am. Bankr. L.J. 501, 540 (1993) (reporting that lawyers who represent consumer debtors describe their clients' feelings and attitudes as "de jected, ashamed, humiliated," and, although sometimes asserting that "the sense of social stigma about bankruptcy has 
bankruptcy stigma remains a potent force in preventing many individuals from filing for bankruptcy who might otherwise dramatically gain from seeking its protection. ${ }^{68}$

Nonetheless, charges of fading bankruptcy stigma have recently intensified. ${ }^{69}$ While there seems to be a perception of a recent decline in bankruptcy stigma in the United States, no vigorous empirical study has yet directly demonstrated it. The absence of such a study is partly due to the difficulty in measuring societal changes in attitude over time towards bankrupts. ${ }^{70}$ Nonetheless, a number of studies have recently attempted to

been waning in recent years," saying that their "clients are still often embarrassed or ashamed"); Sheila Driscoll, Note, Consumer Bankruptcy \& Gender, 83 Geo L.J. 525,541 (1994), summarizes comments made during a focus group session of bankrupts as follows:

Many [clients] have a strong bias against bankruptcy. They see it not only as a last resort but something bad and they require a lot of counseling for them to appreciate that they need to do it. One said, "My mother would turn over in her grave if she knew I was filing for bankruptcy." . . . They feel [they] have committed a terrible sin and are ashamed to admit ... they can't pay their bills. They don't want other members of their family to find out, they wonder whether it can be kept out of the newspapers. ... I had one woman who was crying the whole time she was signing. But it was a matter of either your house in an hour from now, or sign.

How They Did it: A Credit Rehabilitation After Bankruptcy Filing, N.Y. Times, May 14, 1994, at 36 ("Along with overcoming financial troubles, he spent about two years recovering from the trauma and the embarrassment of bankruptcy.").

68 See White, supra note 63 (finding that only a small portion of the individuals who efficiently could file choose to do so).

69 See. e.g., State of Wisconsin v. Galdine, 492 N.W.2d I 88 (Wis. Ct. App. 1992) (judge concluding that the prejudicial effect of the evidence relating to the prior bankruptcy was limited particularly in light of the reduced stigma associated with bankruptcy filing); Trevor Armbrister, Nation of Deadbeats?, Reader's Digest, Sept. 1998, at 167 ("There is no longer any stigma attached to declaring personal bankruptcy, and some consumers now regard bankruptcy as the latest entitlement - a cost-fiee way to enjoy the American Dream."); Braucher, supra note 67, at 540 ("many lawyers said the sense of social stigma about bankruptcy has been waning in recent years"); Damon Darlin, The Newest American Entitlement, Forbes, Sept. 8, 1997, at 113 ("With the stigma of debt and baskruptcy gone, an increasing number of Americans are filing for bankruptcy."); Editorial, Making it Harder to Dodge Debts, Roanoke Times \& World News, May 14, 1999, at Al 4 ("Bankruptcy, much like unwed pregnancy, seems to have no stigma or shame attached to it these days."); Michael Higgins, Putting Back the Bite, 84 A.B.A. J., June 1998, at 74, 75 (noting bankruptcy's diminishing social stigma as filing have become more common).

70 See, e.g. , Mann, supra note 44, at 255 ("there is no evidence that bankruptcy has ever lost its stigma"); Jean Braucher, Increasing Uniformity in Consumer Bankruptcy: Means Testing as a Distraction and the National Bankruptcy Review Commission's 
indirectly measure changes in bankruptcy stigma. Some of these studies have found that bankruptcy stigma remains potent. ${ }^{71}$ However, most of the studies

Proposals as a Starting Point, 6 Am. Bankr. Inst. L. Rev. 1, 7 (1998) ("The stigma associated with bankruptcy is difficult to measure. Solid empirical, as opposed to anecdotal, evidence that it has decreased is hard to come by."); A. Mechele Dickerson, Bankruptcy Reform: Does the Lind Justify the Means?, 75 Am. Bankr. L.J. 243, 267 (2001) ("Though critics claim that the stigma previously associated ... with filing for bankruptcy has all but disappeared, it is virtually impossible to substantiate that claim."); David B. Gross \& Nicholas S. Souleles, An Emprical Analysis of Personal Bankrupecy and Delinquency, 15 Rev. Fin. Stud. 319, 321 (2002) ("The various costs of default, especially social, legal and information costs, are inherently difficult to measure."); Margaret Howard, $A$ Theory of Discharge in Consumer Bankrupky, 48 Ohio St. L.J. 1047, 1061 (1987) (noting lack of data to support the "psychological dimension of bankruptcy known as stigma"); Charles A. Luckett, Personal Bankrupecies, in The Impact of Public Policy on Consumer Credit 69, 76 (Thomas A. Durkin \& Michael E. Staten eds., 2001) (noting that "none of the typically cited social or legal factors are easily quantifiable"); David A. Moss \& Gibbs A. Johnson, The Rise of Consumer Bankruptcy: Evolution, Revolution. or Borh?, 73 Am. Bankr. L.J. 311,327 (1999) ("The biggest problem with the stigma explausation [for the increase in bankruptcy filings] is that we simply do not have much hard evidence regarding the magnitude or significance of bankruptcy stigma, either over time or at a particular moment in time."); Todd J. Zywicki, Institutions, Incentives \& Consumer Bankruptcy Reform 31 (2005) (George Mason University School of Law, Law \& Economics Working Paper Series, No. 05-07, on file with author) ("empirically measuring changes in broad and dif fise social factors, such as shame and stigma is difficult and [these factors] do not easily lend themselves to direct testing").

71 See, e.g., Fragile Middle Class, supra note 67, at 32 ("Discharging debts that were honestly incurred seems the antithesis of middle-class morality. Public identification as a bankruptcy debtor is embarrassing at best, devastating at worst. Bankrupt debtors have told us of their efforts to conceal their bankruptcy."); Kartik Aithreya, Shame as it Lver Was: Stigma and Personal Bankruptcy, 90 Fed. Res. Bauk Rich. Econ. Q. 1, 3 (2004) ("Therefore, a main conclusion of this article is that stigma is by no means dead."); Teresa A. Sullivan, Bankruptcy and the Social Meaning of Credit 10 n.6 (June 1991) (unpublished paper presented at the annual meeting of the Law \& Society Association in Amsterdam, on file with author); Deborah K. Thorne, Personal Bankruptcy through the Eyes of the Stigmatized: Insight into Issues of Shame, Gender and Marital Discord 73, 78-79, 94, 267 (2000) (unpublished Ph.D. dissertation, Washington State University) (on file with author) (based on survey results of petitioners, the researcher found that prior to filing, the majority of bankruptcy petitioners viewed bankruptcy as stigmatizing, were reluctant to file and did not want their friends and family to know about their filing); White, supra note 63, at 205 (estimating, based on a national sample, that at least $15 \%$ of households could benefit from filing for bankruptcy, yet the personal filing rate represents less than $1 \%$ of the adult population. The author suggests that one explanation for the disparity is the powerful influence of stigma); Frederick 
that have attempted to measure bankruptcy stigma have concluded that it has been lessening. ${ }^{72}$

To measure bankruptcy stigma these studies have consistently used indirect variables as proxies for the effects of stigma. For example, a number of studies have used the number of bankruptcy filings as a proxy for declining stigma. ${ }^{73}$ Other studies have concluded that bankruptcy stigma has declined as reflected in the rise of bankruptcy advertising, ${ }^{74}$ changes in community

C. Yeager, Personal Bankruptcy and Economic Stability, 41 S. Econ. J. 96 (1974) (pointing to the stable relationship over time between the personal filing rate and the household debt-to-income ratio as an indication that a change in bankruptcy stigma was unlikely).

72 See, e.g., Visa, Consumer Bankruptcy: Causes and Implications (1996) (claiming that a reduction in stigma and changes in other social factors prompted the rise in personal bankruptcy filings between 1981 and 1996); F.H. Buckley \& Margaret F. Brinig, The Bankruptcy Purzle, 27 J. Legal Stud. 187, 188 (1998) (concluding that a lessening of stigma and other social norms was responsible for the increase in personal bankruptcy filing rates between 1980 and 1991); Scott Fay et al., The Bankruptcy Decision: Does Stigma Matter? (Jan. 1998) (University of Michigaul Working Paper 98-01, on file with author) (asserting that a reduction in stigma of bankruptcy contributed to the increase in the personal bankruptcy filing rate in the early 1990s); David B. Gross \& Nicholas S. Souleles, Explaining the Increase in Bankruptcy and Delinquency: Stigma Versus Risk-Composition (1998) (unpublished manuscript, on file with author) (claiming that a reduction in stigma led to a rise in the number of bankruptcy filings between 1995 and 1997).

73 Siee Paul C. Bishop, A Time Series Model of the U.S. Personal Bankruptcy Rate 1, 8 (1998) (FDIC Bank Trends series) (finding a "large difference" between actual bankruptcy filing rates and the rates that would be predicted based on various household economic distress indicators, which "suggests that there are other factors of importance," such as changes in social norms); Buckley \& Brinig, supra note 72, at 188 ("the explosion in bankruptcy filings is in substantial part attributable to a shift in social norms [not legal] and economic variables"); Scott Fay, Erik Hurst \& Michelle White, The Household Bankruptcy Decision, 92 Am. Econ. Rev. 706, 716 (2002) ("These results are consistent with local trends occurring in which increases in a district's bankruptcy filing rate cause attitudes toward bankruptcy to become more favorable and therefore individual households' probability of filing rise."); David B. Gross \& Nicholas S. Souleles, An Empirical Analysis of Personal Bankruptcy and Delinquency 22 (1998) (Wharton Financial Institutions Center Working Paper 98-28) (showing credit card holders 1\% more likely to file bankruptcy in 1997 than 1995, controlling for household risk-composition along several dimensions. The authors' interpretation is that bankruptcy stigma has decreased).

74 See The Rise in Personal Bankruptcy: Causes and Impact: Hearing Before the Subcomm. on Commercial and Admin. Law of the House Comm. on the Judiciary, 105th Cong. 18019 (1998) (testimony of Stuart A. Feldstein, President of SMR Research) (finding that "cities with high bankruptcy filing rates usually do have higher levels of lawyer advertising than cities with low filing rates"); Diane Ellis, The Influence of Legal Factors on Personal Bankruptcy Filings 98-103 (1998) 
size, as well as migration patterns. ${ }^{75}$ Also, a series of credit industry studies has determined that bankruptcy stigma has lessened, as evidenced by the increased number of petitioners finding out about bankruptcy from family and friends. ${ }^{76}$ Yet another study concluded that bankruptcy stigma has declined as evidenced by the rise in the number of bankruptcy filings filed by nondelinquent debtors. ${ }^{77}$ Lastly, one credit industry-sponsored study relied on

(FDIC Bank Trends series) (finding that increases in the rate of bankruptcy filing have correlated strongly with increased expenditures on legal advertising following a 1977 Supreme Court decision that struck down restrictions on such advertising, Bates v. State Bar of Arizona, 433 U.S. 350 (1977)).

75 See John M. Barron et al., Monitoring the Household Sector with Aggregate Credit Bureau Data, 2000 Bus. Econ. 63, 71 (using the proxy of population density levels to ascertain the role of social norms in bankruptcy filing); Buckley \& Brinig, supra note 72 , at 188 (the authors regressed the consumer bankruptcy filing rates for 86 districts against legal, economic and social variables. Variables used as proxies for the strength of social networks were rates of migration and the percentage of the population living in a metropolitan area. They concluded that legal and economic variables were unable to account for the increase in filing rates, but that social variables were "powerful predictors" of filing rates); Fay, Hurst \& White, supra note 73 , at 712 (using cross-section data, the authors tried to identify time series trends within various communities that suggest a lower level of disapproval of bankruptcy over time in given communities); Teresa Sullivan et al., As We Forgive Our Debtors 244-46 (1989) (noting correlation of migration history with propensity to file bankruptcy).

76 See VISA, 2000 Life After Bankruptcy Study 5 (2000) ("The increasing trend in the number of people learning about bankruptcy through friends and family members has been demonstrated in each annual debtor survey, and is once again confirmed in this study."); VISA, Consumer Baukruptcy: Annual Bankruptcy Debtor Survey 2 (1997) ("Fully 45.3 percent of the respondents said they learned about bankruptcy as an option from friends or family. That's a substantial increase over the previous year's 10.5 percent and, taken together with other research inf ormation, suggests a further weakening of the once strong social stigma against bankruptcy.").

77 See Consumer Debt: Hearing Before the House Comm. on Banking and Financial Sernices, 104th Cong. 331 (1996) [hereinafter Consumer Debt Hearing] (testimony of Dr. Lawrence Chimerine, Managing Director and Chief Economist of Economy Strategy Institute and Consulting Economist for MasterCard International Incorporated):

The share of bankruptcy filers who have never been delinquent on any loan appears to now be $50 \%$ or higher, and has risen sharply in recent years. This suggests that factors other than debt are increasingly driving the process. This is far different than the situation which prevailed in earlier decades, when bankruptcy was generally a last resort. . . . Today, bankruptcy is increasingly becoming first option, and the old time profile no longer appears to be representative.

Bankruptcy Law Revision: Hearing Be fore the Subcomm. on Commercial and Admin. law of the House Comm. on the Judiciary, 105th Cong. 5 (1998) (testimony of 
the rise in the number of bankruptcy petitioners who did not pursue credit counseling prior to filing, ${ }^{78}$ and the alleged rise in the number of repeat filers, ${ }^{79}$ as evidence for declining bankruptcy stigma.

These various attempts to measure bankruptcy stigma have been roundly criticized. In addition to their over-reliance on proxies for ascertaining the decline in bankruptcy stigma, ${ }^{30}$ these findings have also been criticized for focusing on questioning former petitioners to ascertain existing stigma levels. Since the bankruptcy population is not sufficiently representative of

Malloıy B. Duncan, Vice President, General Counsel of National Retail Federation) (noting that for many retailers "more than $40 \%$ of the bankruptcy petitioners received are from customers (often long-standing) who are not seriously delinquent").

78 See Consumer Debt Hearing, supra note 77, at 428-29 (written statement of VISA U.S.A. Inc.):

Of course, there are many reasons for these [personal bankruptcy filings] increases. But surely one reason is that bankruptcy no longer appears to carry the social stigma it once did. . . . In a Visa survey of individuals who filed for bankruptcy during a 12-month period in 1995 and $1996 \ldots$. less than half of the respondents sought credit counseling before deciding to file for bankruptcy, further evidence that an increasing number of people appear to choose bankruptcy as the "solution" to their financial difficulties rather than as a "last resoit."

79 See id. (concluding that baukruptcy no longer carriers the stigma it once did, the author refers to the results of a survey of bankruptcy petitioners finding that "almost $14 \%$ of the respondents had filed for bankruptcy two or more times").

80 See Congressional Budget Office, Personal Bankruptcy: A Literature Review, at xi (2000):

Several studies maintain that the social stigma associated with filing for bankruptcy plays a significant role in determining the filing rate, but at best, those findings are merely suggestive. Because direct measures of stigma do not exist, the studies used other variables as proxies - that is, to approximate the effects of stigma. However, the proxy variables did not isolate stigma's influence on the filing rate.... Consequently, the studies probably overstated the effects of stigma.

Fragile Middle Class, supra note 67, at 264 ("Most recent analyses of the 'decline in stigma of bankruptcy' do not use any direct measure of stigma."); Thorne, supra note 71 , at 70 (criticizing a previous study, that relied on bankruptcy proxies to conclude that bankruptcy stigma has declined, for failure to operationalize the crucial independent variable of stigma); Gross \& Souleles, supra note 73, at 3:

Unfortunately it has been difficult to disentangle the risk and stigma effects empirically. First, it is not obvious how to operationalize the stigma effect. Most of the proxies for stigma that have been suggested run into the problems of endogeneity and reverse causality. For example, consider using the number of advertisings by bankruptcy lawyers as an inverse proxy for stigma. The problem is that an increase in ads might not be the cause of the rise in bankruptcies, but rather their effect. 
the general population, questioning former petitioners does not provide a reliable indicator of the general public's perception. ${ }^{81}$

\section{An Empirical Studv on Stigma in BankRuptcy: a Content Analysis of NewsP.aper Articles}

\section{A. Research Methodology and Justification}

This study attempts to measure the evolution of stigma in bankruptcy by addressing the methodological deficiencies attributed to previous empirical studies on this subject. Rather than measuring bankruptcy stigma through the examination of proxies or through the questioning of former petitioners, this study measures evolving public perception about bankruptcy by examining the general public's expressed sentiments.

To ascertain whether the negative image of bankrupts has eroded in the United States over the past centuiy and a half, 176 newspaper articles published between 1864 and 2002 were examined for content. ${ }^{82}$ Examination of the content of consumer bankruptcy related newspaper articles provides valuable insight into the evolution of public perception of bankrupts during that period.

This study chose the popular print media as its corpus because it is the most inclusive, providing a forum for disparate communities and individuals to exchange ideas and debate proposals. It functions as the general population's quasi town square, providing a daily chronicle of how social problems are defined and perceived within society.

Often embedded within newspaper articles on consumer bankruptcy are important messages about the appropriateness of filing for bankruptcy, the causes of bankruptcy filings, and the validity of debt relief provisions in a bankruptcy regime. While messages communicated in newspaper articles

81 See Margaret Howard, Bankruptcy Empiricism: Lighthouse Still No Good, 17 Bank. Dev. J. 425, 453 (2001) (book review):

researchers who have attempted to study the stigma of bankruptcy have done so by looking at debtors. . . . Until a statistically valid study of the general population's attitude toward the stigma of bankruptcy is undertaken, we should have no patience with assertions of declining stigma or with arguments for statutory change that are justified by resort to those assertions.

Zywicki, supra note 70, at 62 n.256.

82 Of the 176 newspaper articles published, 69 were published before 1970 and 107 were published subsequently. 
do not precisely reflect general attitudes of the populace, this study attempts to indirectly identify such messages in a sample of newspaper articles and to use the embedded messages as a measure for broad and evolving societal perceptions about the bankruptcy population. While messages embedded in newspaper articles influence public opinion, these messages also reflect existing public opinion. ${ }^{83}$

The articles were selected from the New York Times. The New York Times was selected because it is among the most widely circulated daily newspapers in the United States and serves as a relatively good representation of mainstream print media. Another reason for choosing the New York Times was its diverse readership and its national scope. Lastly, the New York Times is the only mass circulated newspaper that has its content indexed as far back as the mid-nineteenth century.

The New York Times Index was used to identify articles about consumer bankruptcy between 1864 and 2002. The search began with the year 1864 because that was the first year the New York Times began indexing its articles; hence making it possible to efficiently locate articles about bankruptcy. Articles were located under the keyword "bankruptcy." Only articles that discussed the use of personal bankruptcy, the causes of personal bankruptcy, the appropriateness of personal bankruptcy filing, or the scope of debt relief that should or should not be available to individuals in bankruptcy were selected under the "bankruptcy" heading. Items incorporated in the sample included news reports, letters to the editor, feature articles, and commentary.

Excluded from the sample were articles that were not completely or substantially about personal bankruptcy; articles written by current or former bankrupts; articles on topics other than personal bankruptcy (i.e., corporate or municipal bankruptcy); articles about bankruptcy in other countries; or articles exclusively discussing the administration of the bankruptcy system.

83 See Philip O. Buck et al., Media and Professional Interest in Homelessness Over 30 Years, 4 Analyses Soc. Issues \& Pub. Pol'y 151 (2004) ("In addition to the possibility that media coverage may influence public opinion, media coverage may also reflect public opinion ...."); Yael Har-Even, Emigration as a Social Problem: Emigration fiom Israel as Reflected in "Letters to the Editor" of Ha'Aretz, 1949-1987, at 52 (unpublished M.A. thesis, Tel-Aviv University) (on file with the Tel-Aviv University Library) (employing content analysis of letters to the editors to evaluate shifting public opinion in Israeli society regarding emigration fiom lsrael); Steve Stemler, An Orerview of Content Anal ysis, 7(17) Prac. Assessment Res. \& Evaluation (2001) ("Additionally, content analysis provides an empirical basis for monitoring shifts in public opinion."). 
A total of 176 newspaper articles meeting these criteria were found. The sample contains more articles from after 1970 (107) than before $1970(69)$.

Once the sample of articles was collected, four content evaluators coded the articles. A questionnaire was developed to evaluate and assist the content evaluators in their assessment of the articles. The content evaluators were three research assistants, all undergraduate students, in addition to the principal investigator. The content evaluators completed the coding independently, in separate rooms, and were instructed not to discuss their work with each other.

The task of coding articles for content was explained to the content evaluators before they began coding, and their understanding of the questionnaire was examined. The principal investigator went over the questionnaire with the content evaluators and made sure that they understood the questions in the questionnaire and how to complete it.

Following the training of the content evaluators, the content evaluators were instructed to code all of the articles in the sample. The content evaluators were given the same articles to evaluate, in the same order.

After reading and independently analyzing each article assigned to him or her from the sample, each content evaluator filled out a questionnaire. The questionnaire required the content evaluator to: (a) identify the date of the article; (b) identify the article type (news report, feature article, column, commentary, letter to the editor); (c) identify whether the article primarily discussed merchant debtors or consumer debtors; and (d) assess the disposition of the article towards the bankrupt or the bankruptcy population.

To identify articles that displayed a favorable attitude towards bankrupts or towards the bankruptcy population, the content evaluators were asked to examine the following: (a) whether any of the following keywords were attributed to the bankrupt or the bankruptcy population: moral, truthful, pure, responsible, fair, victim, oppressed, thrift, suffering, hardworking, conscientious, struggle, facing hardship, perseverance, deserving support; or (b) whether the article attributed the bankruptcy filings to events beyond the control of the petitioners, or to the actions of third parties (i.e., creditors). Articles regarded as positive were so marked and received the numerical value of three.

Similarly, to identify articles that displayed an unfavorable attitude towards the bankrupt or the bankruptcy population, the content evaluators were asked to examine the following: (a) whether any of the following keywords were attributed to the bankrupt or the bankruptcy population: irresponsible, unf air, fraudulent, outcast, exploiter, abusers, misbehaving, immoral, neglectful, threatening community well-being, lazy, dependent, freeloader, deceiver; or (b) whether the article attributed the bankruptcy to 
the debtor's lack of responsibility or other negative character istics. Articles regarded as negative were so marked and received the numerical value of one. Articles including both favorable and unfavorable references to the bankrupt or the bankruptcy population, or no references at all, were deemed neutral and given a score of two. The content evaluators were required to provide a written explanation for the basis of their assessments.

The content evaluators' numerical assessments were averaged for each examined article. An average was then computed for all articles in a given year. The average score for each year between 1864 and 2002 was recorded on an excel spreadsheet and subjected to data mining.

This research design has several limitations. Primarily, the messages communicated in newspaper articles in general, and in the New York Times in particular, do not precisely reflect broad populace attitudes. Instead, this research design uses the embedded messages as a proxy for broad and evolving societal perceptions about the bankruptcy population. Also, while the content evaluators were guided in their assessments, in order to achieve some degree of objectivity (i.e., the use of keywords to ascertain the predispositions exhibited in the articles), there is no way to eliminate all subjectivity inherent in such evaluations. Furthermore, the keywords that guided the content evaluators were potentially limiting and not entirely inclusive. In addition, given the large number of years covered in this study, it is inevitable that the New York Times' readersh ip and journalists have changed over the years. Moreover, the absence of any other national circulating and indexed newspaper that dates back to the 19th century left us with only one newspaper as the corpus. Similarly, given the national scope of the New York Times, the study's methodology was unable to fully capture regional disparities in social attitudes. Lastly, at the time this research was initiated, no nationally circulating newspaper had its articles available in an electronic format going all the way back to the 19th century. Searching a database of electronically formatted articles may have yielded additional articles for our sample compared to the yield of the manual indexing system that was available to us at the time this study was undertaken. Given these limitations, the results discussed below should not be construed as a definitive statement on evolving norms in bankruptcy, but rather, as a supplement to existing studies on the subject and an examination of norms in bankruptcy through a different lens. 


\section{B. The Results}

Portrayal of bankruptcy petitioners in the New York Times newspaper articles shifted dramatically in the 1960s. Prior to the 1960s, newspaper articles depicted debtors largely as manipulators and fraud promoters. Debtors in bankruptcy were represented as a manifestation of the decline of societal moral values and were frequently referred to as evil doers, cheaters, crooks, fools, or perjurers. Similarly, newspaper articles from prior to the 1960 s commonly a1tributed bankruptcy filing to the debtor's transgressions. Bankruptcy filings were usually attributed to the debtor's fraudulent conduct, such as concealment of assets. ${ }^{84}$

In contrast, beginning in the 1960 s, bankruptcy petitioners were no longer regularly ref erred to as deceitful. Instead, newspaper articles began referring to the petitioners merely as irresponsible or unethical individuals who lack discipline. ${ }^{35}$ Aside from transforming the portrait of bankruptcy petitioners from intentionally corrupt to simply rash and immature, the new discourse also incorporated sympathetic undertones. For the first time, petitioners were depicted in newspaper articles in compassionate terms. Petitioners were ref erred to as hardworking, poor, struggling, and needy. ${ }^{86}$ Visuals used along

84 See, e.g., After the Frauds Among Bankrupts, N.Y. Times, N॰v. 4, 1923 (referring to an increase in fraudulent bankruptcies as "evil" and as "commercial lawlessness"); Judge Hough on Bankrupicy Frauds, N.Y.. Times, Jan. 17, 1912, at 14 (referring to bankrupts as an army of swindlers); The Bankruplcy Inguiry, N.Y. Times, June 12, 1881 (asserting that debtors in bankruptcy cheat their creditors); Compeling with Fraud, N.Y. Times, May 10, 1878 (referring to petitioners as evil and declaring that bankruptcy filing is a product of fiaud committed by petitioners and amounts to a manifestation of shrinking values); Fraudulent Failures, N.Y. Times, April 23, 1878 , at 1 (referring to bankruptcy filings as "fraudulent failures" and suggesting that bankruptcy law promotes fraud); The Bankruplcy Acl, N.Y. Times, Feb. 29, 1868 , at 1 (emphasizing a bankruptcy anendment provision that refers to debtor's fiaud and deceit).

85 See, e.g., David J. Morrow, Key 10 a Cozier Bankruplcy: Localion, Location, Localion, N.Y. Times, Jan. 7, 1998, at Al ("More bankruptcy filings, critics say, have translated into more abuses."); Saul Hansell, Baltle Emerging on Hov 10 Revise Bankruptcy /anw. N.Y. Times, Oct. 19, 1996, at A1 (referring to petitioners as deadbeats); Clint Willis, Your Money: Caution Advised on Bankruplcy, N.Y. Times, Mar. 12, 1988, at A38 ("Some employers assume that a bankruptcy filing indicates that a person is irresponsible or untrustworthy."); id. (declaring that extravagant spending leads to more bankruptcies); Michael deCourcy Hinds, Are Changes Needed in Bankruplcy Lenvs?, N.Y. Times, May 31, 1982, at Bl ("Today, it is fashionable for these debtors to take straight bankruptcy not as a matter of need but out of convenience.").

86 See. e.g., Martin Fisher, Beller Bankrupıcy, N.Y. Times, Oct. 26, 1997, at IV.14 
with an article on bankruptcy commonly incorporated pictures of the poor, the disabled, the petitioner holding a baby, the unsophisticated blue-collar worker, along with the white-collar worker ${ }^{87}$ Unlike bef ore, when bankruptcy was viewed in articles as quasi criminal, it was now perceived and referred to as a matter of basic civil liberties and consumer rights. ${ }^{88}$

Moreover, beginning in the 1960s, newspaper articles discontinued attributing bankruptcy filings to debtors' fraud. Instead, bankruptcy filings began to be viewed largely as a product of events beyond the control of the petitioners. Newspaper atticles frequently pointed to economic conditions that promoted the debtors' bankruptcy filings, such as recession, high inflation, unemployment, stock market losses, a decline in housing prices, an increase in foreclosures, or an increase in overall personal debt. ${ }^{89}$ Alternatively, some articles attributed bankruptcy filings to personal misfortune, such as an auto accident, illness, divorce, high medical bills, or other unforeseen hardships. ${ }^{90}$ Lastly, articles began to ascribe bankruptcy

("Most bankruptcy cases are filed by ordinary middle-class people who are employed and contribute to society."); Tamar Lewin, Lively Debate on Bankruptcy, N.Y. Times, Aug. 9, 1983 ("it would be wrong to deny a fiesh start to poor people who have gotten into debt"); William Robbins, Why 5 People Found Themselves in Bankruptcy, N.Y. Times, Oct. 2, 1982, at $\mathrm{Cl}$ (providing accounts of petitioners who are hard working and honest but failed due to reasons beyond their control); Williaun E. Geist, Rising Bankruptcies in Suburbia, N.Y. Times, Mar. 30, 1982, at II.2 ("The people filing for baukruptcy now are decent, hard-working people, not phonies. They just wanted to live the American Dream and now find it costs too much.").

87 See: e.g., Peter Kilborn, Mired in Debt and Seeking a Path Out, N.Y. Times, Apr. I, 2001, at I.I (including a picture of petitioners holding their grandson. The petitioners were described as an unemployed disabled couple); Robbins, supra note 86 (portraying petitioners in a positive light using pictures of three petitioners, all of whom are serious, thoughtful and dressed respectably).

88 See, e.g., Bankruptcy Debate, N.Y. Times, May 16, 1983, at IV.2 (indicating that pro-debtor bankruptcy groups include consumer rights group, civil rights groups and labor unions); Robert A. Wright, Personal Bankruptcies are Rising, N.Y.. Times, May 9, 1971, at III.3 ("[Bankruptcy] gives them a fresh start . ... Otherwise, their problems would drive them to drink, narcotics, or suicide. Bankruptcy is a very human course.").

89 See Nick Ravo, Personal Bankruptcies Mounting with the Trepidation Lessening, N.Y. Times, Jan. 21, 1991, at B4 (attributing bankruptcy to business failure, loss of job, mounting household debt, declining home equity, ailing economy, and unemployment); Willis, supra note 85 ("circumstances like prolonged illness or job loss also account for many bankruptcies"); id. ("People who are sued for repayment of debt or who face imminent foreclosure on their home may have little alternative but to file for bankruptcy."); Hinds, supra note 85 (suggesting that rising bankruptcy filings are a product of a depressed economy and unemployment).

90 See, e.g., Kilborn, supra note 87 ("But many of the Americans who go bankrupt 
filings to the fault of third parties, such as the government's failure to provide an adequate safety net, ${ }^{91}$ lawyers' increased bankruptcy advertising, ${ }^{92}$ and creditors' reckless lending practices. ${ }^{3}$

In addition to a more favorable depiction of debtors and a more sympathetic view of the causes of bankruptcy filings (i.e., economic conditions, personal misfortune, and fault of third parties), newspaper articles also reflected a more favorable disposition towards the operations of the bankruptcy system. Aiticles began referring to the bankruptcy system as a system of "legal protection," ${ }^{14}$ as the "federal fresh stait program,"

have only hard luck to blame."); Legislation to Oherhaul Lans on Bankruptcy Dies as President Fails to Sign It, N.Y. Times, Dec. 20, 2000, at A32 (attributing bankruptcy filings to "unforeseen hardships" alnong other things); Saul Hansell, Personal Bankruptcies Surging as Economy Hums, N.Y. Times, Aug. 25, 1996, at Al (attributing bankruptcy filings to serious illness, divorce, and medical bills, among other things).

91 See, e.g., Hansell, supra note 90 (attributing bankruptcy filings to lack of a safety net, among other things).

92 See Robert Bennett, who Pays,for Bankruptcies, N.Y. Times, June 3, 1983, at D2 (congressman attributing increase in bankruptcy filings to a Supreme Court ruling allowing lawyers to advertise).

93 See, e.g., Philip Shenon, Senators Adopt Tougher Rules on Bankruptcy, N.Y. Times, March 16, 2001, at AI ("The bill's critics say that credit card companies and other lenders are themselves largely to blame for the explosion in bankruptcy specifically, that their mass solicitations for high-interest credit cards and other loans have encouraged irresponsible spending that has landed borrowers in bankruptcy court."); Stephen Labaton, House Vores 10 Make it Tougher to Escape Debt Through Personal Bankrziptcy, N.Y. Times, May 6, 1999, at A28 (reporting that "the record number of personal bankruptcies was as much a result of the easy extension of credit"); Hansell, supra note 90 (describing practices of credit card companies of giving higher credit to people they previously shunned and suggesting that the lenders may be most responsible for bankruptcy's growing appeal by showering Americans with unsolicited credit cards); Robert Bennett, supra note 92 ("The problem [of rising bankruptcies] is not the bankruptcy law itself but profligate lending by bauks and finance companies.").

94 See New Bankruptcy Law: Creditors, Debrors Aided, N.Y. Times, Oct. 19, 1979, at DI (concluding that bankruptcy reform provides "protection" for petitioners).

95 See Robert Hershey Jr., Creditors Lead Push to Curb Bankruptcy, N.Y. Times, May 10, 1998, at III.10 (asserting that proposed bankruptcy legislation "constitutes an assault on the long-established principle that society needs a mechanism to give the hopelessly indebted a fresh start"); Ravo, supra note 89 ("Bankruptcy has a bad name,' Mr. Carron, the Westport lawyer, said. 'What it really is is the Federal Fresh Start program.'"). 
wise financial strategy, ${ }^{96}$ or as an informal and easy process for dealing with temporary setbacks.?

The shift in the depiction of bankruptcy petitioners beginning in the 1960s was also statistically confirmed. The hypothesis that this study purported to test was that societal attitudes regarding bankruptcy petitioners began to change in the late 1960s as a result of the cultural revolution taking place in the United States at that time. ${ }^{98}$ To validate this hypothesis, the ratings for the newspaper articles from the New York Times for the years I 864 through 1969 were compared with the mean annual ratings for articles from 1970 through 2002 using a t-test. The mean rating from bef ore 1970 was 1.768 . The mean rating on or after 1970 was more favorable at 2.165. This change is significant at an alpha of .001. Hence, the data suggest that the attitudes of the American people about bankruptcy petitioners changed in the United States following the 1960s and have become more sympathetic towards bankruptcy petitioners.

The ratings of the newspaper articles were also examined relative to other independent variables, including a time series analysis of the years between 1864 and 2002, gross domestic product, the unemployment rate, the number of bankruptcy filings, available consumer credit, change in gross domestic product, change in unemployment rates, change in the number of bankruptcy filings, change in available consumer credit, party affiliation of the President, party affiliation of the majority in the House of Representatives, and party affiliation of the majority in the United States Senate. Using simple, multiple, step-wise regressions, the results identified no other strong, significant statistical relationship between the variables. ${ }^{99}$

96 S'ee, e.g., Hansell, supra note 90 ("Bankruptcy often looks like a good deal.").

97 See. e.g., Morrow, supra note 85 ("Some lawmakers contend that declaring personal bankruptcy is now too easy . . . ."); Hansell, supra note 90 (describing informality and ease of the bankruptcy process); Personal Bankrupicy: Credirors. Debrors \& Elhics, N.Y. Times, Oct. 12, 1975, at III.I6 (suggesting that bankruptcy is an easy process).

98 See generally Roger Kimball, The Long March: How the Cultural Revolution of the 1960s Changed America (2000).

99 The only other statistically significant relationship was identified using a simple regression between mean annual ratings and the unemployment rate. The relationship was significant at about .02. The R-square was low, however. Hence the relationship was weak but significautt. Interestingly, the relationship was negative. That is, the higher the unemployment rate, the more negatively bankruptcy petitioners were viewed in society. 


\section{Conclusion}

This study detected a noticeable shift in public attitudes beginning in the 1960s towards individuals filing for personal bankruptcy in the United States. Importantly, however, this study did not find that changing public perception necessarily prompted an increase in bankruptcy filings. Correspondingly, an important recent study comparing bankruptcy filing rates in a database of six different countries seems to have excluded stigma as a significant contributor to the disparities in filing rates among these countries. Specifically, the study found that changes in gross domestic product, credit card debt, credit card spending, and consumer credit can explain about ninety percent of the variation in bankruptcy filing rates in the database of these six countries. ${ }^{100}$ Nonetheless, other studies on bankruptcy stigma have found an increase in the probability of debtors filing for bankruptcy when the level of bankruptcy stigma falls. ${ }^{|0|}$ Perhaps all of these studies taken together suggest that the impact of the apparent shift in social perception of bankruptcy in the United States has had but a limited influence, if any, on bankruptcy filing rates.

100 See Ronald J. Mann, Credit Cards, Consumer Credit, and Bankruptcy (March 2005) (University of Texas School of Law, Law \& Economics Working Paper Series, Number 044 , on file with author).

101 See Fay, Hurst \& White, supra note 73, at 1. 